\title{
Kepemimpinan Transformasional Kepala Sekolah dalam Meningkatkan Prestasi Sekolah
}

\author{
Fauzuddin 1 \\ ${ }^{1}$ Manajemen Pendidikan-Universitas Negeri Malang
}

\section{INFO ARTIKEL}

\section{Riwayat Artikel:}

Diterima: 20 Juni 2018

Disetujui: 11 Oktober 2018

\section{Kata kunci:}

Kepala sekolah

Pendekatan kualitatif

Studi multikasus

Gaya kepemimpinan

\begin{abstract}
ABSTRAK
Abstract: This research is aimed at exploring in depth about the principals leadership at two Senior High Achieving Schools and one Islamic Senior High Achieving Schools in Banda Aceh. This research was conducted by using qualitative approach along with multi-case design. The data collecting technique used was in-depth interview, participation observation, and documentation study. The results of the research showed that the transformational leadership style used by the principals is very effective in developing schools become high achieving schools.
\end{abstract}

\begin{abstract}
Abstrak: Penelitian ini bermaksud untuk mengungkapkan lebih mendalam tentang kepemimpian kepala sekolah pada dua Sekolah Menengah Atas dan satu Madrasah Aliyah Negeri berprestasi di Kota Banda Aceh. Penelitian ini menggunakan pendekatan kualitatif dengan rancangan studi multikasus. Teknik pengumpulan data menggunakan wawancara mendalam, ob-servasi partisipasi, dan studi dokumentasi. Hasil dari penelitian ini menunjukkan bahwa gaya kepemimpinan transfor-masional yang diterapkan oleh kepala sekolah sangat efektif dalam menciptakan sebuah sekolah menjadi berprestasi.
\end{abstract}

\section{Alamat Korespondensi: \\ Fauzuddin \\ Manajemen Pendidikan \\ Pascasarjana Universitas Negeri Malang \\ Jalan Semarang 6, Malang 65154 \\ E-mail: fauz-sjs@yahoo.com}

Reformasi pendidikan sebagai bagian dari reformasi kehidupan berbangsa dan bernegara telah cukup lama dimuali di Indonesia. Diawali dengan diterapkannya UU No. 22 Tahun 1999 tentang otonomi daerah dan Peraturan Pemerintah No. 25 Tahun 2000 tentang pembagian wewenang antara Pemerintah Pusat dan Daerah Otonom. Salah satu kewenangan yang turut bergeser di era reformasi adalah bidang pendidikan. Kewenangan penyelanggaraan pendidikan yang dulu sangat kental dengan pola-pola sentralistik bergeser menjadi kewenangan daerah dengan segala implikasi dan pertimbangan kondisi serta kebutuhan daerah masing masing.

Densentralisasi pendidikan di Indonesia merupakan suatu bentuk rekonstruksi kebijakan pemerintah terhadap penyesuaian pelaksanaan otonomi daerah. Pada perkembangan sebelumnya, nampaknya permasalahan pendidikan diklasifikasikan sebagai akibat dari adanya bentuk sentralisasi kebijakan pendidikan, dimana segala aspek keberagaman potensi dipadukan secara seragam, sehingga telah banyak menciptakan kondisi kualitas sumber daya manusia yang kurang inovatif, dan cenderung bergantung pada pemerintah dan tidak mandiri. Aspek keseragaman yang saat itu ditetapkan dalam prinsip sentralisasi, pada konsep desentralisasi menunjukkan adanya sasaran keberagaman, baik dari segi potensi peserta didik, maupun pengembangan potensi lingkungan daerah.

Bukti-bukti empirik yang menunjukkan bahwa manajemen berbasis pusat merupakan salah satu faktor yang menyebabkan kurang optimalnya kinerja sekolah adalah perlu diterapkanya manajemen berbasis sekolah (MBS). Esensi MBS adalah otonomi sekolah plus pengambilan keputusan partisipatif. Otonomi sekolah adalah kewenangan sekolah untuk mengatur dan mengurus kepentingan warga sekolah menurut prakarsa sendiri berdasarkan aspirasi warga sekolah sesuai dengan peraturan perundang-undangan 
pendidikan nasional yang berlaku. Maka, untuk menjalankan sebuah sekolah, faktor yang akan menentukan performa sebuah sekolah agar menjadi sebuah sekolah yang baik dan bermutu adalah faktor kepemimpian.

Kepemimpinan dalam pendidikan telah mengalami perubahan yang pesat sebagai konsepsi dari perubahan organisasi dan reformasi sekolah dalam abad ke 21 ini. Dengan banyak teori yang muncul dan ditulis oleh para ahli pendidikan, kepemimpinan pendidikan sekarang dapat dilihat dari berbagai sudut pandang dengan cara yang lebih sensitif oleh masyarakat terhadap dilema moral dan etika, (Muflihin, 2008). Banyak cara yang muncul dalam memberikan konsep terhadap kepemimpinan pendidikan, dan penelitian ini mendiskripsikan bagaimana kepe-mimpinan transformasional kepala sekolah dalam meningkatkan prestasi sekolah pada tiga sekolah menengah atas yang berprestasi di Banda Aceh.

Sekolah yang berprestasi pasti memiliki sistem pengembangan sekolah yang terintegrasi dan terimplementasi dalam proses pembelajaran. Sekolah juga telah melakukan inovasi-inovasi kegiatan budaya sekolah dan terinventarisasikannya budaya sekolah yang sesuai dengan nilai-nilai lokal, nasional, dan internasional. Semuanya itu telah menyatu ke dalam kegiatan akademik dan kegiatan kesiswaan melalui kegiatan yang bersifat intrakurikuler dan ekstrakurikuler sehingga nantinya sekolah itu akan menjadi sekolah yang memiliki perolehan prestasi yang tinggi (high achieving school).

Tuntutan sekolah yang profesional membutuhkan pengelolaan yang tepat. Dengan pengelolaan yang tepat, lembaga dapat menginventarisir kekuatan-kekuatan dan kebutuhan-kebutuhannya, kelemahan, peluang, hambatan, dan tantangan yang mungkin ada. Dari analisis tersebut akan tampak perbedaan karakteristik sebuah sekolah dengan sekolah lainnya. (Sergiovanni, 2005) menyarankan agar para pengambil kebijakan, para penilik, dan kepala sekolah menggunakan pendekatan budaya sekolah atau school culture approach dalam mengembangkan sekolah. Alasannya: Pertama, pendekatan budaya lebih menitikberatkan faktor manusia di atas faktor-faktor lainnya. Peran manusia amat sentral dalam suatu proses perubahan berencana. Manusia adalah faktor yang menentukan keberhasilan perubahan, bukan struktur atau peraturan legal. $K e d u a$, pendekatan budaya menekankan pentingnya peran nilai dan keyakinan dalam diri manusia. Aspek ini merupakan elemen yang sangat berpengaruh dalam membentuk sikap dan perilaku. Karenanya, pendekatan budaya menomorsatukan transformasi nilai dan keyakinan terlebih dahulu sebelum perubahan yang bersifat legal-formal. Ketiga, pendekatan budaya memberikan penghormatan dan penerimaan terhadap perbedaanperbedaan yang ada. Sikap menerima dan saling hormat menghormati akan menciptakan rasa saling percaya dan kebersamaan di antara anggota organisasi. Rasa kebersamaan akan memunculkan kerja sama, dan kerja sama akan mewujudkan sikap profesionalisme yang membawa perubahan sehingga mengubah nilai-nilai lama yang menghambat dengan nilai-nilai baru yang mendukung keberhasilan sekolah hingga menjadi sekolah yang berprestasi.

Pengelola sekolah harus membangun sebuah sistem yang di dalamnya mengutamakan kerjasama atau team-work. Kesuksesan dibangun atas dasar kebersamaan dan bukan kerja satu orang kepala sekolah atau one man show. Bahkan kepala sekolah harus bisa memahami bahwa dirinya juga sebagai salah satu anggota tim. Sebagiman yang diungkapkan (Giancola \& Hutchison, 2005).

When leaders in a culture consider themselves members of a team, their limits of commitment to the organization, dedication to the professional community and love of children are maximized. The leaders of the culture must consider themselves members of the team. It does not good for one or two leaders to try to bestow or empower a sense of team membership among all the others.

Kepala sekolah memiliki peran yang sangat penting dalam memberi arah kepada sekolah yang sukses. (Supriadi, 2009) menyatakan bahwa erat hubungannya antara mutu kepala sekolah dengan berbagai aspek kehidupan sekolah seperti disiplin sekolah, iklim budaya sekolah dan menurunnya perilaku negatif peserta didik. Dalam pada itu kepala sekolah bertanggung jawab atas manajemen pendidikan secara mikro, yang secara langsung berkaitan dengan proses pembelajaran di sekolah. Sebagimana dikemukakan dalam Pasal 12 ayat 1 PP Nomor 28 tahun 1990 bahwa: "Kepala sekolah bertanggungjawab atas penyelenggaraan kegiatan pendidikan, administrasi sekolah, Pembinaan tenaga kependidikan lainnya, dan pendayagunaan serta pemeliharaan sarana dan prasarana".

Kepala sekolah harus memahami budaya sekolah yang ada sekarang ini, dan menyadari bahwa hal itu tidak lepas dari struktur dan pola kepemimpinannya. Perubahan budaya yang lebih "sehat" harus dimulai dari kepemimpinan kepala sekolah. Kepala sekolah harus mengembangankan kepemimpinannya berdasarkan dialog, saling perhatian dan pengertian satu dengan yang lain (Fullan, 2001). 
Menurut (Permadi, 2001) dalam mewujudkan bentuk layanan prima yang di lakukan kepala sekolah adalah: (1) Sekolah harus memiliki visi, strategi, misi dan target mutu yang ingin dicapai. (2) Menciptakan lingkungan yang aman dan tertib, (3) Menciptakan sekolah yang memiliki kepemimpinan yang kuat, (4) Adanya harapan yang tinggi dari personal sekolah untuk berprestasi, (5) Adanya pengembangan staf sekolah secara terus-menerus sesuai tuntutan ilmu pengetahuan dan teknologi (IPTEK), (6) Adanya pelaksanaan evaluasi yang berkelanjutan terhadap berbagai aspek pengajaran dan administtrasi serta pemanfaatan hasilnya untuk perbaikan mutu, dan (7) Adanya komunikasi dan dukungan intensif dari orang tua dan masyarakat.

Menurut (Gorton, 1977; Sergiovanni, 1987) sekolah merupakan institusi yang kompleks, dan tidak akan menjadi baik dengan sendirinya kecuali dengan pengelolaan yang baik dan dengan inovasi tertentu. Dalam proses itu kepala sekolah dan personalia sekolah melakukan berbagai usaha agar sebuah sekolah menjadi baik. (Sergiovanni, 1987) menyebutkan bahwa sekolah-sekolah yang berprestasi secara akademik seringkali disebut sebagai sekolah yang efektif (effective), sukses (success), dan unggul (excellent).

Dalam kenyataan, berbagai tuntutan terhadap kinerja kepala sekolah masih belum dapat dipenuhi, seperti masih banyaknya sekolah yang siswanya memiliki prestasi rendah, ketidakdisiplinan siswa dan guru, kurangnya kemampuan guru dalam mengelola pembelajaran, penguasaan sebagian guru terhadap bidang keilmuan/mata pelajarannya belum memadai dan lambannya staf pengajar dan pegawai sekolah dalam melayani kebutuhan siswa. Masalah-masalah ini merupakan cerminan kurangnya kemampuan kepala sekolah dalam memberdayakan bawahannya dalam berkinerja tinggi. Kepala sekolah seharusnya mampu mengelola semua sumber daya yang ada secara efektif dan efesien untuk mencapai tujuan pendidikan disekolah.

Dari segi kepemimpinannya, dalam era globalisasi seperti sekarang ini, seorang kepala sekolah perlu mengadopsi gaya kepemimpinan transformasional, agar semua potensi yang ada di sekolah dapat berfungsi secara optimal (Wuradji, 2008). Kepemimpinan transformasional merupakan bentuk kepemimpinan yang mengilhami para pengikutnya untuk lebih mementingkan diri mereka sendiri demi kebaikan organisasi, dan yang mampu memberikan efek yang mencolok dan luar biasa pada diri pengikutnya (Robbins, 2003). Secara umum pemimpin transfor-masional mencurahkan perhatian pada hal-hal dan kebutuhan pengembangan diri pengikutnya secara individual. Mereka mengubah kesadaran para pengikut terhadap persoalan yang dihadapi dengan membantu mereka memandang masalah lama dengan cara-cara baru. Mereka mampu menggairahkan, membangkitkan dan mengilhami para pengikut untuk mengeluarkan upaya ekstra demi mencapai tujuan kelompok.

(Bass, 1997) mengemukakan bahwa "kepemimpinan transformasional sebagai pengaruh pemimpin atau atasan terhadap bawahan. Para bawahan merasakan adanya kepercayaan, kebanggaan, loyalitas dan rasa hormat kepada atasan, dan mereka termotivasi untuk melakukan melebihi apa yang diharapkan". "Kepemimpinan transformasional harus dapat mengartikan dengan jelas mengenai sebuah visi untuk organisasi, sehinggga para pengikutnya akan menerima kredibilitas pemimpin tersebut" (Giancola \& Hutchison, 2005).

Untuk menjawab berbagai permasalahan yang dihadapi di sekolah, pola kepemimpinan transformasional merupakan salah satu pilihan bagi kepala sekolah untuk memimpin dan mengembangkan sekolah yang berkualitas. Kepemimpinan transformasional memiliki penekanan dalam hal pernyataan visi dan misi yang jelas, penggunaan komunikasi yang efektif, pemberian rangsangan intelektual, serta perhatian pribadi terhadap permasalahan individu anggota organisasinya (Danim \& Suparno, 2009). Dengan penekanan pada hal-hal seperti itu, diharapkan kepala sekolah akan mampu meningkatkan kinerja staf pengajar di sekolahnya dalam rangka mengembangkan kualitas sekolah. Penerapan kepemimpinan transformasional juga diperlukan karena berbagai informasi terkini seyogianya dapat ditransformasikan kepada guru, tenaga administrasi, siswa dan orang tua melalui komunikasi persuasif, psikologis, dan edukatif dari kepala sekolah.

Tujuan penelitian ini adalah untuk mendeskripsikan tentang a) peran kepala sekolah dalam mengembangkan visi dan misi sekolah, b) kepemimpinan kepala sekolah dalam melakukan perubahan disekolah, dan c) dukungan kepala sekolah terhadap teransformasi individu guru.

\section{METODE}

Penelitian ini dilakukan dengan menggunakan pendekatan kualitatif. Pendekatan kualitatif digunakan untuk mengungkapkan data deskriptif dari informan dari apa yang mereka lakukan, rasakan, dan yang 
mereka alami terhadap fokus penelitian. Pendekatan penelitian kualitatif dipandang paling sesuai dengan tujuan penelitian ini, yaitu untuk mendeskripsikan peran seseorang atau aktivitas yang dilakukan seseorang dalam latar kapasitasnya sebagai pengurus organisasi dalam hal ini kepala sekolah. Laboratarium penelitian kualitatif adalah kehidupan sehari-hari dan tidak dapat dimasukkan kedalam tabung, tidak dapat dimulai dan diakhiri, dan tidak dapat dimanipulasi (Morse, 1994).

Rancangan penelitian ini adalah dengan studi multi-kasus (multi-case study). Berdasarkan rancangan studi multikasus, maka ancangan penelitian ini menggunanakan metode komparatif konstan (the constant comparative method) yang menurut (Bogdan \& Biklen, 2003) merupakan rangkaian langkah yang berlangsung sekaligus dan analisisnya selalu berbalik kembali ke pengumpulan data dan pengkodean. Yin (1984) berpendapat apabila pokok pertanyaan penelitian berkenaan dengan "how" dan "why" serta berkaitan dengan lebih dari satu kasus maka penelitian tersebut harus menggunakan desain studi multikasus.

Penelitian ini dilakukan di dua SMA Negeri berprestasi dan satu MA Negeri berprestasi di kota Banda Aceh dengan menggunakan teknik pengumpulan data (1) wawancara mendalam (in depth interview), (2) observasi partisipan (participant observation) (3) Studi dokumentasi (study documents). Kepala sekolah pada masing-masing sekolah sebagai sumber data yang paling utama untuk mendapatkan data tentang kepemimpinan yang berlangsung di sekolah. Untuk memperkuat data yang diperoleh dari informan kunci maka peneliti juga mencari informasi dari berbagai informan lainnya. Elemem-elemen sekolah yang secara langsung dan tidak langsung berhubungan dengan kepala sekolah atau mendapat dampak dari kepemimpinan kepala sekolah.

Sumber data penelitian kualitatif sebagaimana dinyatakan (Arikunto \& Suharsimi, 2002) dapat berupa orang (person), tempat (place), dan symbol (paper). Sedangkan menurut (Spradley, 1980) menunjuk pada tiga elemen, yaitu pelaku (actor), activitas (activity), dan tempat (place).

Berdasarkan kedua pendapat di atas, sumber data penelitian ini terdiri atas empat katagori sebagai berikut: (1) Sumber data berupa orang/pelaku, dalam hal ini kepala sekolah, wakil kepala sekolah, guru, pegawai administrasi dan komite sekolah, (2) Sumber data berupa tempat, yaitu MAN Model, SMA Negeri 3, dan SMA Negeri 10 Fajar Harapan Banda Aceh yang ketiganya dipilih menjadi obyek penelitian ini. (3) Sumber data berupa aktivitas, dalam hal ini merujuk kepada berbagai aktivitas yang mengarah kepada upaya kepemimpinan kepala sekolah dalam mengembangkan sekolah menjadi sekolah yang baik, yang memiliki prestasi akademik dan non akademik siswa yang tinggi. (4) Sumber data berupa simbol (paper) yakni berupa simbol-simbol kelembagaan, atribut sekolah, atribut siswa dan sebagainya yang turut mempengaruhi proses perubahan sekolah melalui kepemimpinan transformasional kepala sekolah.

Penelitian ini menggunakan dua analisis data, yaitu analisis data kasus individu dan analisis data lintas kasus. Menurut (Yin, 2009) dalam menganalisis data rancangan penelitian multikasus dilakukan dua tahap, yaitu analisis data kasus individu (individual cases) dan analisis data lintas kasus (cross-cases analysis). Penganalisisannya dilakukan sebagaimana yang dianjurkan oleh (Mantja, 2007; Miles \& Huberman, 2007), yaitu (1) data reduction (reduksi data), (2) data display (penyajian data), dan (3) conclusion drowing (kesimpulan sementara, verifikasi dan kesimpulan akhir). Ketiga alur analisis data tersebut merupakan suatu kesatuan, prosesnya saling berkaitan dan berulang-ulang selama dan sesudah pengumpulan data.

\section{HASIL}

Berdasarkan analisis data diperoleh temuan penelitian sebagai berikut: Dalam mengembangkan visi/misi sekolah, kepala sekolah (1) melibatkan semua unsur sekolah dalam menciptakan visi dan misi sekolah, (2) terlebih dahulu melakukan observasi dan mendalami budaya sekolah yang ada, kekuatan dan kelemahan sekolah, di awal-awal kepemimpinannya, (3) merumuskan visi dan misi sekolah untuk tujuan jangka panjang, jangka menengah dan jangka pendek, (4) Visi sekolah dipahami sebagai penunjuk arah perubahan ke masa depan dan sebagai gambaran dari keadaan masa depan sekolah yang diinginkan bersama, (5) berupaya memberikan pemahaman mendasar akan visi dan misi sekolah kepada semua warga sekolah dan masyarakat, (6) berharap visi dan misi sekolah dapat menjadi alat dalam mengembangkan pribadi siswa untuk menjadi orang-orang yang cerdas, berkualitas, berbudi luhur melalui suasana belajar yang aman, tentram, damai, berlandaskan Imtaq/Iptek yang tidak terlepas dari budaya daerah, (7) Visi dan misi sekolah dikomunikasikan untuk dihayati dan diimplementasikan kepada semua komunitas sekolah sehingga terwujud dalam budaya sekolah yang kuat, (8) Untuk mencapai harapan-harapan melalui visi dan misi, kepala sekolah melakukan langkah langkah edukatif melalui a). pendidikan yang dilandasi oleh nilai-nilai keislaman yang tinggi 
(IMTAQ), b). peningkatan proses pembelajaran, c). peningkatan kualitas individu guru, d). membina hubungan yang harmonis antara sekolah, orang tua, masyarakat, dan instansi terkait, dan d). mempersiapkan siswa untuk menjadi manusia yang unggul, disiplin trampil, kreatif, jujur, dan bertanggungjawab.

Dalam melakukan perubahan di sekolah, kepala sekolah (1) mengelola sekolah dengan pola kepemimpinan yang demokrasi, (2) memberikan kepercayaan kepada bawahan dengan tidak membeda-bedakan antara mereka, (3) menghargai dan mengapresiasi semua prestasi yang dilakukan para guru dan siswanya, (4) membangun kedisiplinan agar suasana sekolah menjadi tertib dan nyaman, (5) membentuk tim kerja yang kuat (6) menyelenggarakan pendidikan ketrampilan yang mengarah pada pengembangan dan pelestarian budaya, serta pembelajaran ICT sebagai program muatan lokal, (9) memperbaiki dan mengembangkan fasilitas sekolah baik sarana maupun prasarana pendidikan, (10) berperan dalam proses pengambilan keputusan bersama-sama dengan para guru dan pegawainya, (11) Dalam upaya menciptakan budaya dan iklim kerja yang kondusif, kepala sekolah memperhatikan kepada prinsip-prinsip bahwa: a) para guru akan bekerja lebih giat apabila kegiatan yang dilakukannya menarik dan menyenangkan, b) tujuan kegiatan perlu disusun dengan jelas dan diinformasikan kepada para guru, c) para guru selalu diberitahu tentang maksud dari setiap pekerjaannya, d) pemberian hadiah lebih baik dari hukuman, e) perlu memenuhi kebutuhan sosiopsiko-fisik guru, untuk memperoleh kepuasan, (12) Perilaku kepala sekolah lebih menjadi kolega dari pada atasan terhadap para guru dan pegawai, dan (13) memberikan pembinaan kepada guru dan pegawai.

Dukungan yang diberika kepala sekolah terhadap transformasi individu guru antara lain (1) kepala sekolah mendorong para guru agar dapat secara terus menerus meningkatkan kompetensinya melalui kegiatan supervisi pengajaran, pemberdayaan MGMP, mengikutsertakan guru dalam penataran dan pelatihan, kursus, workshop, dan memberikan kesempatan untuk melanjutkan pendidikan ke jenjang yang lebih tinggi, (2) mengajak guru untuk melakukan penelitian dan suka menulis sebagai tujuan dalam meningkatkan kualitas individu guru, (3) memberi tugas pembimbingan kepada guru. Mereka (para guru) diberi kewenangan untuk membina kelompok-kelompok kreativitas siswa, seperti pembinaan olimpiade, musik dan tari, olahraga, pidato, dan multimedia, (4) mengalokasikan anggaran sekolah untuk pembinaan guru yang diperoleh melalui hasil musyawarah dengan komite sekolah, (5) Bersama-sama guru mengembangkan, mencari, dan menggunakan metode mengajar sesuai dengan tuntutan kurikulum yang berlaku (6) Membina kerjasama yang baik dan harmonis antar warga sekolah (7) menghadirkan tokoh-tokoh pendidikan ke sekolah untuk meningkatkan pengetahuan guru, (8) melakukan supervisi kelas sebagai bantuan bagi guru yang masih memiliki kekurangan dalam mengajar dan memberikan apresiasi bagi mereka yang mampu mengelola kelas dengan baik. Supervisi yang dilakukan tidak untuk mencari-cari kesalahan dan kekurangan namun lebih bersifat preventif, korektif dan kooperatif, (9) bekerjasama dengan pengawas sekolah dalam menghadapai guru di sekolah.

\section{Pembahasan}

\section{Peran kepala sekolah dalam mengembangkan visi dan misi sekolah}

Kejelasan dalam menterjemahkan visi dan misi ke dalam aksi-aksi yang terukur dengan kriteria kompetensi ilmu pengetahuan dan keterampilan yang jelas dalam tiap disiplin ilmu merupakan bagian penting dalam menerapkan standar. Visi dan misi sekolah memiliki nilai dan tujuan yang akan dicapai. Sebuah nilai menyatakan prinsip-prinsip dasar ideologi, aturan, dan aspirasi yang dianut oleh seluruh anggota organisasi (guru/pegawai, kepala sekolah, dan siswa) dalam men-capai visi, misi, dan tujuan organisasi sekolah. Tujuan menunjukkan target atau arah hendak ke mana organisasi sekolah itu akan dibawa. Tujuan dapat dibedakan menjadi dua: tujuan jangka penjang (long range planing) dan tujuan jangka pendek (short range planing). Keduanya tercermin dalam sistem perencanaan.

Data membuktikan bahwa sampai pada pernyataan visi dan misi, ketiga kepala sekolah memiliki cita-cita yang tinggi. Harapan yang tinggi sangat berpo-tensi dan menjadi sumber semangat peningkatan mutu pendidikan/sekolah. Per-nyataan visi-misi dari ketiga sekolah berprestasi tersebut tergambar seperti beri-kut: (1) Semua sekolah memiliki perhatian yang baik mengenai pentingnya per-nyataan visi dan misi. Semua sekolah menegaskan perhatian pada peningkatan keimanan, penguasaan ilmu pengetahuan, dan penguasaan teknologi, (2) Mempublikasikan visi dan misi pada berbagai kesempatan dan media sebagai pernyataan formal sekolah, (3) Mendeskripsikan secara umum pada konsentrasi sekolah dalam meningkatkan kompetensi 
siswa dalam bidang ilmu pengetahuan dan teknologi, (4) Menunjukkan kuatnya keyakinan bahwa sekolah dapat berprestasi sebagaimana harapan yang dideskripsikan pada visi dan misi sekolah yang ideal. (5) Kepala sekolah mempelajari kekuatan dan kelemahan sekolah atau analisis SWOT yang akan menjadi petunjuk dalam merumuskan misi, tujuan dan sasaran yang ingin dicapai sekolah. Kepala sekolah dapat mengembangkan visi dengan berkolaborasi sehingga tumbuh iklim yang kondusif bagi berkembangnya inisiatif warga sekolah untuk mencapai tujuan dengan standar mutu yang tinggi.

\section{Kepemimpinan Kepala Sekolah dalam Melakukan Perubahan di sekolah}

Keberhasilan manajemen suatu organisasi ditentukan oleh efektivitas ke-pemimpinannya, karena kepemimpinan adalah inti dari manajemen. Oleh sebab itu seorang pemimpin harus memiliki dan melaksanakan kepemimpinannya de-ngan baik agar memperoleh kesuksesan dalam melaksanakan tugasnya.

Keberhasilan seorang pemimpin akan terwujud apabila pemimpin tersebut memperlakukan orang lain atau bawahannya dengan baik, serta memberikan moti-vasi agar mereka menunjukkan performance yang tinggi dalam melaksanakan tugas.

Dalam dunia pendidikan kepala sekolah mempunyai peranan yang penting dalam pencapaian tujuan pendidikan. Tanpa adanya kepala sekolah sebagai pim-pinan maka pendidikan sukar untuk berhasil, hal ini disebabkan akan fungsi dari kepala sekolah sebagai pemimpin untuk mempengaruhi, mendorong, mengarahkan, dan menggerakkan warga sekolah untuk bersama-sama bekerja mencapai tujuan sekolah/tujuan pendidikan. Sebagaimana diungkapkan (Nawawi \& Martini, 1994), bahwa kepemimpinan kependidikan adalah proses menggerakkan, mempengaruhi, memberikan motivasi dan mengarahkan orang-orang di dalam organisasi/lembaga pendidikan tertentu untuk mencapai tujuan yang telah dirumuskan sebelumnya. Untuk mewujudkan tugas tersebut setiap pemimpin pendidikan harus mampu bekerjasama dengan orang-orang yang dipimpin untuk memberikan motivasi agar melakukan pekerjaan secara ikhlas dan lebih lanjut.

Ketiga kepala sekolah pada tiga sekolah Menengah Atas berprestasi yang menjadi subyek penelitian ini adalah pemimpin pendidikan yang berkualitas ka-rena keberadaan mereka memberikan kesuksesan kepada sekolah yang dipim-pinnya.

Karakteristik kepemimpinan yang efektif dari ketiga Sekolah ini sesuai dengan kriteria yang ditetapkan (Dubin, 1991) yaitu mampu memenihi tiga hal, yaitu (1) menciptakan iklim yang kondusif bagi siswa untuk belajar (create atmosphere conducive for student learning), (2) para guru terlibat dan berkembang (teacher involvement and growth), (3) seluruh masyarakat menberikan dukungan dan menaruh harapan yang tinggi (community support and high expectations).

\section{Bentuk-Bentuk Bantuan atau Dukungan yang Diberikan Kepala Sekolah terhadap Transformasi Individu Guru}

Dalam kadar tertentu, kepala sekolah sebagai pimpinan sebuah unit kerja, memainkan peran yang sama seperti halnya manajer unit kerja lainnya. Kepala sekolah harus dapat memastikan bahwa sistem kerjanya berjalan lancar dan semua sumber daya yang diperlukan untuk mencapai hasil harus tersedia secukupnya dengan kualitas yang memadai. Namun, kepala sekolah mengelola sebuah lembaga yang sangat istimewa yaitu sekolah sebagai lembaga formal pendidikan yang akan sangat me-warnai masa depan anggota utamanya, yaitu siswa atau peserta didik.

Tentu saja kepala sekolah bukan satu-satunya determinan bagi efektif tidaknya suatu sekolah karena masih banyak faktor lain yang perlu diperhitung-kan. Ada guru yang dipandang sebagai faktor kunci yang berhadapan langsung dengan para peserta didik dan masih ada lagi sejumlah masukan instrumental dan masukan lingkungan yang mempengaruhi proses pembelajaran. Namun, kepala sekolah memainkan peran yang termasuk sangat menentukan. Kepala sekolah adalah pemimpin pendidikan yang bertanggung jawab atas menciptakan lingku-ngan belajar yang kondusif yang memungkinkan anggotanya mendayagunakan dan mengembangkan potensinya seoptimal mungkin. Dalam lingkungan seperti itu, para guru dan peserta didik termotivasi untuk saling belajar, saling memotivasi, dan saling memberdayakan. Suasana seperti itu memberi ruang untuk saling belajar melalui keteladanan, belajar bertanggung jawab, serta belajar mengem-bangkan kompetensi sepenuhnya, bukan sekadar kompetensi kognitif. Kepala sekolah seharusnya berada di garda paling depan dalam hal peneladanan, pemo-tivasian, dan pemberdayaan.

Kegiatan lembaga pendidikan sekolah di samping diatur oleh pemerintah, sesungguhnya sebagian besar ditentukan oleh aktivitas kepala sekolahnya. Menurut (Pidarta, 2004), kepala sekolah merupakan kunci 
kesuksesan sekolah dalam mengadakan perubahan. Sehingga kegiatan meningkatkan dan memperbaiki program dan proses pembelajaran di sekolah sebagian besar terletak pada diri kepala sekolah itu sendiri. (Pidarta, 2004) menyatakan bahwa kepala sekolah memiliki peran dan tanggungjawab sebagai manajer pendidikan, pemimpin pendidikan, su-pervisor pendidikan dan administrator pendidikan.

\section{SIMPULAN DAN SARAN}

\section{Simpulan}

Berdasarkan fokus, paparan data, temuan penelitian, serta analisis dan pembahasan, maka hasil penelitian ini dapat disimpulkan, kepemimpinan kepala sekolah pada tiga sekolah berprestasi ini mempunyai karakteristik sama dengan kepemimpinan transformasional, yaitu dengan memiliki penekanan dalam hal pernyataan visi dan misi yang jelas, penggunaan komunikasi secara efektif, pemberian rangsangan intelektual serta perhatian pribadi terhadap permasalahan individu anggota organisasi sekolah.

Kepala sekolah mengkomunikasikan visi pribadi dan visi sekolah kepada seluruh warga sekolah, orang tua siswa, masyarakat dan pemerintah. Kepala sekolah mempunyai nilai kepemimpinan yang menjadi landasan berfikir dan bertindak dalam memimpin sekolah yaitu (a) disiplin dan berkomitmen bahwa bekerja sebagai ibadah, (b) bersikap demokratis, (c) bertanggung jawab, (d) berani berinovasi dan berani serta yakin pada pembaharuan dan (e) jujur, amanah dan terbuka. Kepala sekolah juga mempunyai hubungan sosial yang terjalin baik dengan warga sekolah antara lain; (1) kesejawatan, (2) keteladanan, (3) menghargai prestasi guru dan siswa, (4) kebersamaan, (5) kekeluargaan, (6) kepedulian, dan (7) kesejahteraan. Hal ini sejalan dengan apa yang dikatakan Luthans, (1995) tentang ciri seorang yang telah berhasil menerapkan gaya kepemimpinan transformasional adalah sebagai berikut: (1) mengidentifikasi dirinya sebagai agen perubahan (pembaruan); (2) memiliki sifat pemberani; (3) mempercayai orang lain; (4) bertindak atas dasar sistem nilai (bukan atas dasar kepentingan individu, atau atas dasar kepentingan dan desakan kroninya); (5) meningkatkan kemampuannya secara terus-menerus; (6) memiliki kemampuan untuk menghadapi situasi yang rumit, tidak jelas, dan tidak menentu; serta (7) memiliki visi ke depan.

Strategi yang dilakukan kepala sekolah dalam meningkatkan prestasi sekolah adalah: (1) optimalisasi proses pembelajaran, (2) memberdayakan dan me-ningkatkan profesionalisme guru dan karyawan sekolah, (3) mendukung transformasi individu guru, (4) pemberdayaan potensi siswa, (5) menjalin kemitraan dan kerjasama dengan berbagai pihak untuk mendukung prestasi siswa, (6) mengoptimalkan pendelegasian tugas, wewenang, dan tanggung-jawab, (7) melakukan studi banding, dan (6) mengoptimalkan penggunaan fasilitas sekolah. Strategi tersebut dilakukan bersamaan karena ada keter-kaitan satu dengan yang lain.

\section{Saran}

Kepada kepala sekolah yang diteliti, disarankan tetap meningkatkan kualitas kepemimpinannya dan tetap mempertahankan image masyarakat tentang sekolah favorit dan berprestasi terhadap ketiga sekolah tersebut dengan terus meningkatkan prestasi akademik dan non akademik siswa. Kepala sekolah senantiasa berusaha semaksimal mungkin merubah pola pikir warga sekolah, dan senantiasa membangun komitmen bersama dengan seluruh warga sekolah dalam mewujudkan visi dan misi sekolah.

Kepala sekolah senantiasa mempertahankan dukungan atau pembinaan yang diberikan kepada guru untuk mengembangkan potensi dirinya melalui kegiatan pendidikan dan pelatihan, semimar, work shop, kursuskursus dan memberikan kesempatan melanjutkan pendidikan kejenjang yang lebih tinggi, khususnya bagi guru yang memiliki minat dan potensi.

Bagi kepala sekolah lain, kepemimpinan transformasional kepala sekolah pada ketiga sekolah yang diteliti ini dapat dijadikan model kepemim-pinan sekolah yang efektif dalam melakukan transformasi budaya sekolah untuk mencapai level sekolah yang berprestasi dan memiliki tingkat lulusan (outcome) sekolah yang tinggi, sehingga dapat dijadikan perbandingan untuk pengembangan sekolah melalui kepemimpinan transformasional kepala sekolah dalam melakukan berbagai perubahan di sekolah pada sekolah lainnya.

\section{DAFTAR RUJUKAN}

Arikunto, A., \& Suharsimi, S. (2002). Prosedur Penelitian: Suatu Pendekatan Praktek. Jakarta: Rineka Cipta.

Bass, B. M. (1997). Does the transactional-transformational leadership paradigm transcend organizational and national boundaries? American Psychologist, 52(2), 130. 
Bogdan, R., \& Biklen, S. (2003). Qualitative Research for Education. An Introduction to Theories and Methods. London: Pearson.

Danim, S., \& Suparno, D. (2009). Manajemen dan kepemimpinan transformasional kekepalasekolahan: visi dan strategi sukses era teknologi, situasi krisis, dan internasionalisasi pendidikan. Rineka Cipta.

Dubin, A. E. (1991). The Principal as Chief Executive Officer. ERIC.

Fullan, M. (2001). Leading in a Culture of Change. Sanfrancisco: John willey \& Sons. Inc.

Giancola, J. M., \& Hutchison, J. K. (2005). Transforming the culture of school leadership: Humanizing our practice. Corwin Press.

Gorton, R. A. (1977). School Administration: Challenge and Opportunity for Leadership. Dubuque, Lowa: Wm. C. Brown Company Publishers.

Mantja, W. (2007). Etnografi Desain Penelitian Kualitatif Pendidikan dan Manajemen Pendidikan. Malang: Elang Mas.

Miles, M. B., \& Huberman, A. M. (2007). Analsisis Data Kualitatif. Jakarta: UI Press.

Morse, J. M. (1994). Critical issues in qualitative research methods. Sage.

Muflihin, M. H. (2008). Kepemimpinan Pendidikan: Tinjauan terhadap Teori Sifat dan Tingkah-laku. Insania, 13(1), 67-86.

Nawawi, H., \& Martini, M. (1994). Kebijakan pendidikan di Indonesia ditinjau dari sudut hukum. Gadjah Mada University Press.

Permadi, D. (2001). Manajemen berbasis sekolah dan kepemimpinan mandiri kepala sekolah. Sarana Panca Karya Nusa, Bandung.

Pidarta, M. (2004). Manajemen Pendidikan Indonesia, Jakarta: PT. Rineka Cipta.

Robbins, S. P. (2003). Perilaku organisasi (Edisi Indonesia). Jakarta: Indeks Kelompok Gramedia.

Sergiovanni, T. J. (1987). The principalship: A reflective practice perspective. ERIC.

Sergiovanni, T. J. (2005). The virtues of leadership. The Educational Forum, 69(2), 112-123. Taylor \& Francis.

Spradley, J. (1980). Participant observation. new York: holt, rinehart und winston. Erlandson, D., Harris, E., Skipper, B. y Allen, S.(1993). Doing Naturalistic Inquiry. En Valles, M.(2000). Técnicas Cualitativas de Investigación Social. Reflexión Metodológica y Práctica Profesional. España: Editorial Síntesis.

Supriadi, O. (2009). Pengembangan profesionalisme guru sekolah dasar. Jurnal Tabularasa, 6(1), 27-38.

Wuradji, M. S. (2008). The Educational Leadership (Kepemimpinan Transformasional). Yogyakarta: Gama Media.

Yin, R. K. (2009). Case study research: Design and methods. The Canadian Journal of Action Research, 14(1), 69-71. 